Review

\title{
The Limbal Epithelial Progenitors in the Limbal Niche Environment
}

\author{
Yuan Zhang1* ${ }^{*}$, Hong Sun ${ }^{2 *}$, Yongsong Liu ${ }^{3}$, Shuangling Chen ${ }^{1}$, Subo Cai ${ }^{4}$, Yingting Zhu ${ }^{1}$ and Ping Guo ${ }^{5 凶}$ \\ 1. Research and Development Department, TissueTech, Inc., 7000 SW 97th Avenue, Suite 212, Miami, FL 33173, USA \\ 2. Department of Ophthalmology, the First Affiliated Hospital of Nanjing Medical University, Nanjing, 210029, China \\ 3. Department of Ophthalmology, Yan' An Hospital of Kunming City, Kunming, 650051, China \\ 4. Department of Ophthalmology, Tongji Hospital, Tongji Medical College, Huazhong University of Science and Technology, Wuhan, 430030, China \\ 5. Shenzhen Eye Hospital, School of Optometry \& Ophthalmology of Shenzhen University, Shenzhen Key Laboratory of Department of Ophthalmology, \\ Shenzhen, 518000, China \\ *The first two authors contributed equally to this manuscript. \\ $\triangle$ Corresponding author: Ping Guo: Shenzhen Eye Hospital, Zetian Road 18, Room 421, Futian District, Shenzhen, 518000, China. Tel 08613924659029; Fax \\ 08675523959500; Email: 2607212858@qq.com
}

(0) Ivyspring International Publisher. Reproduction is permitted for personal, noncommercial use, provided that the article is in whole, unmodified, and properly cited. See http://ivyspring.com/terms for terms and conditions.

Received: 2016.06.21; Accepted: 2016.09.01; Published: 2016.10.18

\begin{abstract}
Limbal epithelial progenitors are stem cells located in limbal palisades of vogt. In this review, we present the audience with recent evidence that limbal epithelial progenitors may be a powerful stem cell resource for the cure of human corneal stem cell deficiency. Further understanding of their mechanism may shed lights to the future successful application of stem cell therapy not only to the eye tissue, but also to the other tissues in the human body.
\end{abstract}

Key words: Limbal epithelial progenitors, stem cell

\section{Introduction}

The human eye, a window to the world, is our important photoreceptive organ. A healthy surface of the eye is critical for proper vision. The anterior surface, usually called ocular surface, is defined by the cornea that is surrounding by conjunctiva. And the important transition zone between them is limbus [1]. The cornea, which forms the central region of the ocular surface, provides more than two-thirds of the eye's refractive power. And it also serves a protective role by providing the defense against desiccation, infection and injury [2]. During the eye development, human cornea is one of the last structures being formed. The human cornea is a lamellar-structured tissue comprised by five layers. The anterior cornea is composed of non-keratinized squamous epithelium. The substantia propria containing collagenous and avascular stroma is sparsely populated with keratocytes (fibroblasts). The inner part is a monolayer tissue termed endothelium. Interestingly, corneal stromal keratocytes and endothelial cells are all derived from the neural crest. Each part is separated by a membrane, anteriorly by Bowman's layer and posteriorly by Descemets membrane $[3,4]$. The corneal epithelium is further divided into three layers: basal, wing, and squames. Basal cells secrete matrix molecules, which is a composition of the basement membrane (BM). Squames can protect against external environment by forming lateral tight junctions, and wing cells play a role in wound healing [5]. The conjunctiva, which is divided into three zones (bulbar, forniceal and palpebral), is a loose and vascularized tissue between sclera and the epidermis of the eyelids [6]. The conjunctiva's most important functions are secretory, facilitated by goblet cells and immune related, carried out by its resident Langerhans cells [7].

\section{Limbal Epithelial Stem Cells}

Stem cells are undifferentiated cells that can be able to provide an unlimited supply of proliferating cells. A large body of research indicated that there is a stem cell pool reside in the limbal basal region named 
limbal epithelial stem cells (LESC). LESC share several features with other somatic stem cells, including small cell size [8], high nuclear to cytoplasmic ratio [9], and lack expression of differentiation markers $[10,11]$. The key characteristics of stem cells are high capacity for self-renewal and poor differentiation. They have long cell cycle time, long life span, error-free proliferation, and the ability to divide in an asymmetric way. Asymmetric division allows one of the daughter cells to maintain stemness and replenish the stem cell pool, while the other daughter cell becomes a "transient amplifying cell" (TAC) that follows the path of differentiation. Transient amplifying cells which have a limited proliferative potential can divide more frequently than stem cells [9]. After differentiation, these cells become "post-mitotic cells" and finally, "terminally differentiated cells", both of which are incapable of division [12].

Accumulative evidence support limbus is the location of LESC. The first experimental evidence for the location of LESC was the movement of pigment from the limbus towards an epithelial defect in rabbit wound healing model [13]. Later, Davanger [1] observed a similar migration and proposed that the Palisades of Vogt (PV) situated in the limbus provided the source of LESC [14]. This movement has been described as centripetal migration. And this migration results in corneal neovascularization, impaired corneal function and conjunctival ingrowth [14]. Cotsarelis et al. [15] revealed that [3H] thymidine labeling could retained in limbal basal epithelial cells (LBEC) for long periods of time, indicating a long cell cycle. LBEC was also found to have higher mitotic activity than central corneal epithelial cells [16, 17]. This population which are small and round appear to be more primitive [8]. Another evidence is that complete $[14,18]$ or partial $[19,20]$ removal of limbal epithelium can lead to abnormal corneal wound healing, and the transplantation of LESC can improve epithelial healing.

The limbal basal region is rich in stem cell markers and lack of differentiation markers. Cytokeratin 19 (CK19) is a marker expressed in both limbal basal cells and conjunctival epithelial cells [6]. $\triangle \mathrm{Np63a}$, well known as a progenitor cell marker, was identified in the LESC using western blot [21]. $\triangle \mathrm{Np} 63 \mathrm{a}$ and ABCG2 expressed in the floating spheres obtained from human central corneal cells [22]. ABCG2 was also found to be expressed increasingly from central cornea to peripheral cornea and finally the limbus [22, 23]. Cytokeratin15 (CK15) is a stem cell marker which is specifically expressed in limbal basal epithelial cells [24, 25]. Other examples are differentiation markers cytokeratin 3(CK3), cytokeratin 12 (CK12) and connexin 43. Stroma in central cornea promoted expression of CK3 while stroma in limbus suppressed it. Limbal basal cells and the adjacent conjunctiva were lack of CK3 [10]. The similar pattern was found in CK12, the corneal specific protein [26]. Connexin 43 only expressed when corneal epithelium was cultured with corneal stroma [27]. However, various scientists used different markers to isolate and characterize native limbal epithelial progenitor cells (LEPC) (Table 1).

Table 1. Markers used to isolate and characterize natively exist LEPC

\begin{tabular}{|c|c|c|c|c|c|}
\hline \multirow[t]{2}{*}{$\begin{array}{l}\text { Author } \\
\text { and year }\end{array}$} & \multirow[t]{2}{*}{ Tissue } & \multicolumn{2}{|c|}{$\begin{array}{c}\text { Markers to } \\
\text { isolate }\end{array}$} & \multicolumn{2}{|c|}{ Markers to characterize } \\
\hline & & + & - & + & - \\
\hline $\begin{array}{l}\text { Ingram, } \\
2005 \text { [28] }\end{array}$ & $\begin{array}{l}\text { Human } \\
\text { umbilical vein } \\
\text { or aortic } \\
\text { endothelium }\end{array}$ & ND & ND & $\begin{array}{l}\text { Flk-1, CD31 } \\
\text { CD144,CD105, } \\
\text { CD146, vWF }\end{array}$ & $\begin{array}{l}\text { CD45 } \\
\text { CD14 }\end{array}$ \\
\hline $\begin{array}{l}\text { Werner, } \\
2003 \text { [29] }\end{array}$ & Mouse spleen & PKH-26 & ND & $\begin{array}{l}\text { CD34, c-Kit, Flk-1 } \\
\text { Sac-1 }\end{array}$ & \\
\hline $\begin{array}{l}\text { Bearzi, } \\
2009[30]\end{array}$ & $\begin{array}{l}\text { Human } \\
\text { myocardium }\end{array}$ & Flk-1 & ND & Flk-1, c-Kit & $\begin{array}{l}\text { CD31, } \\
\text { vWF }\end{array}$ \\
\hline
\end{tabular}

ND: Not Defined.

Apart from those natively existing LEPC in the perivascular niche, LEPC could differentiate from ESC in vitro, with the markers used various from study to study (Table 2), implying a highly heterogeneity of such multipotent progenitor cells. LEPC can be differentiated from LESC spontaneously when cultured in vitro [31], while the presentation of BMP4 could promote such differentiation dramatically [32, 33] [31]. LEPC could be further differentiated into LECs (Table 2). It remains unclear whether limbal stromal niche cells, which is believed to be derived from LNCs expressing LESC markers, can differentiate into LEPC and pericytes, and whether such differentiation requires BMP4 signaling.

The induction from LEPC to LEC in vitro, focus on medium and surface, have been summarized in Table 3.

\section{Limbal Stem Cell Niche}

Stem cell (SC) niche is defined in a highly specialize microenvironment consist of cellular components of extracellular matrix (ECM) and secreted growth factors. Collagenase can, but dispase cannot, isolate the entire limbal basal epithelial progenitors and subjacent mesenchymal cells from the limbal stroma [38-40]. In addition, collagenase in MESCM is the best known method to isolate the LNCs because collagenase in MESCM maintains the expression of the SC markers in fresh isolated LNCs [39]. Furthermore, the collagenase isolated limbal SCs as well as surrounding stromal cells, which are 
identified as niche cells that support SCs [38-44]. These isolated vimentin+ LNCs express embryonic and other SC markers and have a differentiation potential into vascular endothelial progenitors [41] and mesenchymal stem cells which can differentiate into osteoblasts, chondrocytes, and adipocytes [41]. Interestingly, these cells also possess the pericyte phenotype to stabilize the vascular tube-like network formed by HUVEC in 3D Matrigel [41]. The progenitor status of LNCs [39] and their close contact $[38,40]$ with LEPC is critical to prevent corneal differentiation and to retain the limbal epithelial progenitors. Cell aggregation may lead to mesenchymal condensation as the first step of chondrogenesis and subsequent osteogenesis [45-47]. Aggregation of human mesenchymal stem cells (MSCs) into 3D spheroids enhances the effect of anti-inflammation and efficacy of treatment of the diseases characterized by sterile tissue injury and unresolved inflammation [48]. It remains unclear whether such aggregation of NCs mediates quiescence, self-renewal, and progeny production of stem cells.

Cumulative evidence showed that self-renewal of adult stem cells (SC) are regulated in a specialized in vivo microenvironment, termed "niche" $[49,50]$. The limbal SC niche (LSCN) has both anatomic and functional dimensions. It is important and necessary to know where LSCN is before functional dimension is addressed. Anatomically, the LSCN is located at a wave-like structure called "Palisades of Vogt". It has an undulated appearance with invaginations and projections into the deeper layers of the corneoscleral rim around cornea and also, with basal lamina structures. These structures are called limbal crypts [51], which provide a specific environment for limbal stem cells. This structure is highly pigmented due to the presence of melanocytes $[1,52,53]$. Similar to the function of human skin bulge area, melanocytes here may produce melanin pigments and transport it to epithelial cells, which can minimize ultraviolet irradiation damage [54]. Moreover, Palisades of Vogt is surrounded by a vascular network [54] which enables the infiltration of suppressor T-lymphocytes [55] and antigen-presenting Langerhan's cells [56]. The highly vascularized structure provides the SC with nutrient and oxygen [57]. Unlike that of the cornea, the percentage of limbal basal cell membranes with hemidesmosomes was significantly less [58]. And the basement membrane of the limbus is undulating with papillae of stroma extending upward [58] and fenestrated [51, 59]. These features suggest that LESC might interact with underlying limbal stroma cells closely.

Table 2. Induction from ESC to EPC and mature ECs (conditions and markers)

\begin{tabular}{|c|c|c|c|c|c|c|c|}
\hline \multirow[t]{2}{*}{ Author } & \multirow[t]{2}{*}{ Origin } & \multicolumn{3}{|l|}{ From LESC to LEPC } & \multicolumn{2}{|c|}{ From LEPC to mature LECs } & \multirow{2}{*}{$\begin{array}{l}\text { Mature ECs identifying } \\
\text { assay }\end{array}$} \\
\hline & & Medium Base & Inducer & Markers & Medium Base & Inducer & \\
\hline $\begin{array}{l}\text { Park } 2004 \\
{[34]}\end{array}$ & human & hybridoma medium & BMP4 VEGF & Flk-1, CD31 & hybridoma medium & $\begin{array}{l}\text { BMP4 } \\
\text { VEGF }\end{array}$ & Flk-1, CD31 \\
\hline $\begin{array}{l}\text { Ferreira } 2007 \\
{[31]}\end{array}$ & Human & EGM-2 & FBS & Flk-1, CD34, CD31, CD133 & EGM-2 & VEGF & CD31, CD34 and Flk-1 \\
\hline $\begin{array}{l}\text { Lee } 2008 \\
{[35]}\end{array}$ & Murine & hybridoma medium & BMP4 & Flk-1, CD31, CD133 & $\begin{array}{l}\text { Methyl-cellulose } \\
\text { medium cytokines }\end{array}$ & VEGF & Flk-1, CD144 \\
\hline $\begin{array}{l}\text { Purpura } 2008 \\
\text { [36] }\end{array}$ & Human & DMEM & $\begin{array}{l}\mathrm{BMP} 4 \\
10 \mathrm{ng} / \mathrm{mL}\end{array}$ & Flk-1, CD34 & differentiation media & VEGF & CD34 Flk1 \\
\hline $\begin{array}{l}\text { Goldman } 2009 \\
\text { [33] }\end{array}$ & Human & DMEM with KO SR & BMP4 & Flk-1, CD34, CD31, CD144 & $\begin{array}{l}\text { EGM-2 } \\
\text { cytokine }\end{array}$ & $\begin{array}{l}\text { BMP4 } \\
\text { VEGF }\end{array}$ & $\begin{array}{l}\text { Flk-1, CD31, CD144, } \\
\text { CD34, and CD133 }\end{array}$ \\
\hline $\begin{array}{l}\text { Noghero } 2011 \\
\text { [37] }\end{array}$ & Murine & N2B27 medium & BMP4 & $\begin{array}{l}\text { Flk-1, CD31, CD133, } \\
\text { CD144 }\end{array}$ & N2B27 & $\begin{array}{l}\text { hFGF2, } \\
\text { VEGF-A165 } \\
\text { BMP4 }\end{array}$ & Flk-1, CD31, CD144 \\
\hline $\begin{array}{l}\text { Park } 2010 \\
{[32]}\end{array}$ & Human & $\begin{array}{l}\text { ECSM } \\
\text { DMEm/F12 } \\
\text { KO serum } \\
\text { bFGF }\end{array}$ & $\begin{array}{l}\text { BMP4 } \\
\text { PD98059 } \\
\text { VEGF } \\
\text { bFGF }\end{array}$ & Flk-1, CD34, CD31, CD133 & EGM-2 medium & $\begin{array}{l}\text { VEGF } \\
\text { bFGF }\end{array}$ & CD31, CD144 \\
\hline
\end{tabular}

Table 3. Induction from LEPC to LEC in vitro, focus on medium and surface

\begin{tabular}{|c|c|c|c|c|c|}
\hline \multirow[t]{2}{*}{ Author and year } & \multirow[t]{2}{*}{ Origin } & \multicolumn{3}{|l|}{ Induction of LEPC to LEC } & \multirow[t]{2}{*}{ Mature EC Assay } \\
\hline & & Medium Base & GFs & Surface & \\
\hline $\begin{array}{l}\text { Goldman } 2009 \\
\text { [33] }\end{array}$ & Human & $\begin{array}{l}\text { EGM-2 } \\
\text { With cytokine cocktail }\end{array}$ & VEGF 50ng/ml & $\begin{array}{l}\text { 24well plate with } \\
\text { coated Matrigel }\end{array}$ & CD31, CD144, CD34 \\
\hline $\begin{array}{l}\text { Park } 2010 \\
{[32]}\end{array}$ & Human & EGM-2 medium & VEGF bFGF & $\begin{array}{l}\text { coated Matrigel } \\
\text { dishes }\end{array}$ & $\begin{array}{l}\text { Typical morphologies, express CD31, CD144, } \\
\text { vWF, form vascular like structure on Matrigel } \\
\text { and took up acegylated-LDL. }\end{array}$ \\
\hline
\end{tabular}


Little is known about the characteristics of the primary precursor cells in vivo, since it has not yet been possible to isolate the most primitive mesenchymal cell from bulk cultures. One of the hurdles has been the inability to prospectively isolate MSCs because of their low frequency and the lack of specific markers. Recently, some groups have reported the identification and prospective isolation of the most primitive mesenchymal progenitors, both in murine and human adult BM, based on the expression of specific markers like SSEA-1, SSEA-3, SSEA-4, STRO-1, the low affinity nerve growth factor receptor (CD271), mesenchymal stem cell antigen-1 (MSCA-1), CD56 and PDGFR- $\beta$. (Table. 4) Despite the identification of these new MSC markers, none of the markers are the true characteristic mesenchymal progenitors. Indeed, MSCs may be composed by different cell subsets which might be responsible for specific functions and characterized by different cell surface markers. Therefore, further research in this field is warranted in order to identify an MSC-specific marker; this will hopefully allow to dissect the developmental hierarchy of MSCs and will facilitate the generation of homogenous cellular products [60]. However, CD271 ${ }^{\text {bright} / P D G F R-~} \beta+$ bone marrow derived cells has been proved to have the ability to give rise to CFU-F [61], and human endometrium derived MSC are characterized as CD146+/PDGFR- $\beta+$, thus PDGFR- $\beta$ may serve as a marker for MSC precursor cells. Chen et al have prospectively identified and purified vascular pericytes in multiple human organs and shown that these cells are potent mesodermal progenitors that give rise to genuine MSC in culture $[62,63]$.

Table 4. CD34+ or PDGFR- $\beta+$ are identified as typical MSC progenitor markers

\begin{tabular}{|c|c|}
\hline $\begin{array}{l}\text { Author and } \\
\text { year }\end{array}$ & Citations \\
\hline $\begin{array}{l}\text { Corselli } 2012 \\
{[64]}\end{array}$ & $\begin{array}{l}\text { These novel MSC ancestors, which have been typified as } \\
\text { CD34+CD146- cells, can differentiate in culture into } \\
\text { CD34-CD146+ pericytes. }\end{array}$ \\
\hline $\begin{array}{l}\text { Katare } 2011 \\
{[65]}\end{array}$ & $\begin{array}{l}\text { CD34+ cells, located around the vasa vasorum in the } \\
\text { adventitia of arteries and veins, also express typical pericyte } \\
\text { markers (NG2, PDGFR- } \beta \text {, and RGS5) together with } \\
\text { mesenchymal (CD44, CD90, CD73, CD29) and stemness } \\
\text { antigens (Oct-4and Sox-2). This adventitial subset contains } \\
\text { progenitor cells that may contribute to angiogenesis. }\end{array}$ \\
\hline $\begin{array}{l}\text { Campagnolo } \\
2010 \\
{[66]}\end{array}$ & $\begin{array}{l}\text { Total vessel wall cell isolates contain CD34+/CD31- cells } \\
\text { which upon culture express pericyte/mesenchymal markers. } \\
\text { Integrate into vascular networks in vitro and in vivo }\end{array}$ \\
\hline $\begin{array}{l}\text { Traktuev } 2008 \\
{[67]}\end{array}$ & $\begin{array}{l}\text { A population of multipotent } \mathrm{CD} 34+\text { positive adipose stromal } \\
\text { cells share pericyte and mesenchymal surface markers, reside } \\
\text { in a periendothelial location, and stabilize endothelial } \\
\text { networks. }\end{array}$ \\
\hline $\begin{array}{l}\text { Schwab } 2007 \\
{[68]}\end{array}$ & $\begin{array}{l}\text { CD146+PDGFR- } \beta+\text { cells from human endometrium } \\
\text { underwent differentiation into adipogenic, osteogenic, } \\
\text { myogenic and chondrogenic lineages. }\end{array}$ \\
\hline
\end{tabular}

A population of limbal NCs from collagenase-digested clusters and cultured on plastics coated with Matrigel in modified ESCM (ESCM plus $4 \mathrm{ng} / \mathrm{ml} \mathrm{bFGF}$ and $10 \mathrm{ng} / \mathrm{ml}$ LIF), termed MESCM, was successfully used for expansion. Such expanded limbal NCs at P4 could reversible express ESC markers, when reseeded on 3D Matrigel. Specifically, they restored expression of all ESC markers, but further elevated expression of CD34, which is an important marker for angiogenesis progenitors [32, 67, 69]. Dravida et al [70] isolated limbal fibroblast-like cells (LFLC) from the human limbal explants using SSEA4 magic beads and noted that LFLC does not express CD34 while 90\% of the LFLC express CD31, suggesting that such expanded cells on coated Matrigel might turn into EPC. Dravida used SSEA4 magnetic beads to select LFLC, and cultured them on $1 \%$ Matrigel coated plate. In contrast, we expanded the limbal NCs directly from collagenase digested clusters using 5\% Matrigel coated plate. As mentioned in introduction, both LEPC and pericytes could be induced from ESC if given the appropriate condition, thus we speculated that 3D Matrigel could help induce limbal NCs expanded from collagenase digested clusters into angiogenesis progenitors, i.e. LEPC and pericytes.

\section{Conclusion}

Limbal epithelial progenitors are corneal epithelial stem cells, a powerful stem cell resources for cure of human corneal stem cell deficiency. Further studies of their mechanism are required for the future successful application of stem cell therapy to human eye diseases. If successful, such research may impact on the entire field of stem cell research and their clinical applications.

\section{Competing Interests}

The authors have declared that no competing interest exists.

\section{References}

1. Davanger M, Evensen A. Role of the pericorneal papillary structure in renewal of corneal epithelium. Nature. 1971; 229: 560-1.

2. Kolozsvari L, Nogradi A, Hopp B, Bor Z. UV absorbance of the human cornea in the 240- to 400-nm range. Invest Ophthalmol Vis Sci. 2002; 43: 2165-8.

3. Nakatsu MN, Ding Z, Ng MY, Truong TT, Yu F, Deng SX. Wnt/beta-catenin signaling regulates proliferation of human cornea epithelial stem/progenitor cells. Invest Ophthalmol Vis Sci. 2011; 52: 4734-41.

4. Davis J, Duncan MK, Robison WG, Jr., Piatigorsky J. Requirement for Pax6 in corneal morphogenesis: a role in adhesion. J Cell Sci. 2003; 116: 2157-67.

5. Stepp MA, Zieske JD. The corneal epithelial stem cell niche. Ocul Surf. 2005; 3: 15-26.

6. Ang LP, Tan DT. Ocular surface stem cells and disease: current concepts and clinical applications. Ann Acad Med Singapore. 2004; 33: 576-80.

7. Inatomi T, Spurr-Michaud S, Tisdale AS, Zhan Q, Feldman ST, Gipson IK. Expression of secretory mucin genes by human conjunctival epithelia. Invest Ophthalmol Vis Sci. 1996; 37: 1684-92.

8. Romano AC, Espana EM, Yoo SH, Budak MT, Wolosin JM, Tseng SC. Different cell sizes in human limbal and central corneal basal epithelia measured by confocal microscopy and flow cytometry. Invest Ophthalmol Vis Sci. 2003; 44: 5125-9. 
9. Lehrer MS, Sun TT, Lavker RM. Strategies of epithelial repair: modulation of stem cell and transit amplifying cell proliferation. J Cell Sci. 1998; 111 ( Pt 19): 2867-75.

10. Schermer A, Galvin S, Sun TT. Differentiation-related expression of a major $64 \mathrm{~K}$ corneal keratin in vivo and in culture suggests limbal location of corneal epithelial stem cells. J Cell Biol. 1986; 103: 49-62.

11. Kurpakus MA, Stock EL, Jones JC. Expression of the 55-kD/64-kD corneal keratins in ocular surface epithelium. Invest Ophthalmol Vis Sci. 1990; 31: 448-56.

12. Leblond CP. The life history of cells in renewing systems. Am J Anat. 1981; 160: 114-58.

13. Mann I. A Study of Epithelial Regeneration in the Living Eye. Br J Ophthalmol. 1944; 28: 26-40.

14. Huang AJ, Tseng SC. Corneal epithelial wound healing in the absence of limbal epithelium. Invest Ophthalmol Vis Sci. 1991; 32: 96-105.

15. Cotsarelis G, Cheng SZ, Dong G, Sun TT, Lavker RM. Existence of slow-cycling limbal epithelial basal cells that can be preferentially stimulated to proliferate: implications on epithelial stem cells. Cell. 1989; 57: 201-9.

16. Ebato B, Friend J, Thoft RA. Comparison of limbal and peripheral human corneal epithelium in tissue culture. Invest Ophthalmol Vis Sci. 1988; 29: 1533-7.

17. Lindberg K, Brown ME, Chaves HV, Kenyon KR, Rheinwald JG. In vitro propagation of human ocular surface epithelial cells for transplantation. Invest Ophthalmol Vis Sci. 1993; 34: 2672-9.

18. Kruse FE, Chen JJ, Tsai RJ, Tseng SC. Conjunctival transdifferentiation is due to the incomplete removal of limbal basal epithelium. Invest Ophthalmol Vis Sci. 1990; 31: 1903-13

19. Chen JJ, Tseng SC. Abnormal corneal epithelial wound healing in partial-thickness removal of limbal epithelium. Invest Ophthalmol Vis Sci. 1991; 32: 2219-33.

20. Chen JJ, Tseng SC. Corneal epithelial wound healing in partial limbal deficiency. Invest Ophthalmol Vis Sci. 1990; 31: 1301-14.

21. Espana EM, Di Pascuale MA, He H, Kawakita T, Raju VK, Liu CY, et al. Characterization of corneal pannus removed from patients with total limbal stem cell deficiency. Invest Ophthalmol Vis Sci. 2004; 45: 2961-6.

22. Chang CY, McGhee JJ, Green CR, Sherwin T. Comparison of stem cell properties in cell populations isolated from human central and limbal corneal epithelium. Cornea. 2011; 30: 1155-62.

23. Chang CY, Green CR, McGhee CN, Sherwin T. Acute wound healing in the human central corneal epithelium appears to be independent of limbal stem cell influence. Invest Ophthalmol Vis Sci. 2008; 49: 5279-86.

24. Yoshida S, Shimmura S, Kawakita T, Miyashita H, Den S, Shimazaki J, et al. Cytokeratin 15 can be used to identify the limbal phenotype in normal and diseased ocular surfaces. Invest Ophthalmol Vis Sci. 2006; 47: 4780-6.

25. Lyngholm M, Vorum $\mathrm{H}$, Nielsen $\mathrm{K}$, Ostergaard M, Honore B, Ehlers N. Differences in the protein expression in limbal versus central human corneal epithelium--a search for stem cell markers. Exp Eye Res. 2008; 87: 96-105.

26. Chaloin-Dufau C, Sun TT, Dhouailly D. Appearance of the keratin pair $\mathrm{K} 3 / \mathrm{K} 12$ during embryonic and adult corneal epithelial differentiation in the chick and in the rabbit. Cell Differ Dev. 1990; 32: 97-108.

27. Espana EM, Kawakita T, Romano A, Di Pascuale M, Smiddy R, Liu CY, et al. Stromal niche controls the plasticity of limbal and corneal epithelial differentiation in a rabbit model of recombined tissue. Invest Ophthalmol Vis Sci. 2003; 44: 5130-5.

28. Ingram DA, Mead LE, Moore DB, Woodard W, Fenoglio A, Yoder MC. Vessel wall-derived endothelial cells rapidly proliferate because they contain a complete hierarchy of endothelial progenitor cells. Blood. 2005; 105: 2783-6.

29. Werner N, Junk S, Laufs U, Link A, Walenta K, Bohm M, et al. Intravenous transfusion of endothelial progenitor cells reduces neointima formation after vascular injury. Circ Res. 2003; 93: e17-24.

30. Bearzi C, Leri A, Lo Monaco F, Rota M, Gonzalez A, Hosoda T, et al. Identification of a coronary vascular progenitor cell in the human heart. Proc Natl Acad Sci U S A. 2009; 106: 15885-90.

31. Ferreira LS, Gerecht S, Shieh HF, Watson N, Rupnick MA, Dallabrida SM, et al. Vascular progenitor cells isolated from human embryonic stem cells give rise to endothelial and smooth muscle like cells and form vascular networks in vivo. Circ Res. 2007; 101: 286-94.

32. Park SW, Jun Koh Y, Jeon J, Cho YH, Jang MJ, Kang Y, et al. Efficient differentiation of human pluripotent stem cells into functional CD34+ progenitor cells by combined modulation of the MEK/ERK and BMP4 signaling pathways. Blood. 2010; 116: 5762-72.

33. Goldman $\mathrm{O}$, Feraud $\mathrm{O}$, Boyer-Di Ponio J, Driancourt $\mathrm{C}$, Clay $\mathrm{D}$, Le Bousse-Kerdiles MC, et al. A boost of BMP4 accelerates the commitment of human embryonic stem cells to the endothelial lineage. Stem Cells. 2009; 27: 1750-9.

34. Park C, Afrikanova I, Chung YS, Zhang WJ, Arentson E, Fong Gh G, et al. A hierarchical order of factors in the generation of FLK1- and SCL-expressing hematopoietic and endothelial progenitors from embryonic stem cells. Development. 2004; 131: 2749-62

35. Lee D, Park C, Lee H, Lugus JJ, Kim SH, Arentson E, et al. ER71 acts downstream of BMP, Notch, and Wnt signaling in blood and vessel progenitor specification. Cell Stem Cell. 2008; 2: 497-507.

36. Purpura KA, Morin J, Zandstra PW. Analysis of the temporal and concentration-dependent effects of BMP-4, VEGF, and TPO on development of embryonic stem cell-derived mesoderm and blood progenitors in a defined, serum-free media. Exp Hematol. 2008; 36: 1186-98.

37. Noghero A, Arese M, Bussolino F, Gualandris A. Mature endothelium and neurons are simultaneously derived from embryonic stem cells by $2 \mathrm{D}$ in vitro culture system. J Cell Mol Med. 2011; 15: 2200-15.

38. Chen SY, Hayashida Y, Chen MY, Xie HT, Tseng SC. A new isolation method of human limbal progenitor cells by maintaining close association with their niche cells. Tissue Eng Part C Methods. 2011; 17: 537-48.

39. Xie HT, Chen SY, Li GG, Tseng SC. Isolation and expansion of human limbal stromal niche cells. Invest Ophthalmol Vis Sci. 2012; 53: 279-86.

40. Xie HT, Chen SY, Li GG, Tseng SC. Limbal epithelial stem/progenitor cells attract stromal niche cells by SDF-1/CXCR4 signaling to prevent differentiation. Stem Cells. 2011; 29: 1874-85.

41. Li GG, Zhu YT, Xie HT, Chen SY, Tseng SC. Mesenchymal stem cells derived from human limbal niche cells. Invest Ophthalmol Vis Sci. 2012; 53: 5686-97.

42. Chen SY, Mahabole M, Tseng SC. Optimization of Ex Vivo Expansion of Limbal Epithelial Progenitors by Maintaining Native Niche Cells on Denuded Amniotic Membrane. Transl Vis Sci Technol. 2013; 2: 1.

43. Han B, Chen SY, Zhu YT, Tseng SC. Integration of BMP/Wnt signaling to control clonal growth of limbal epithelial progenitor cells by niche cells. Stem Cell Res. 2014; 12: 562-73.

44. Chen SY, Han B, Zhu YT, Mahabole M, Huang J, Beebe DC, et al. HC-HA/PTX3 Purified From Amniotic Membrane Promotes BMP Signaling in Limbal Niche Cells to Maintain Quiescence of Limbal Epithelial Progenitor/Stem Cells. Stem Cells. 2015; 33: 3341-55.

45. Erlebacher A, Filvaroff EH, Gitelman SE, Derynck R. Toward a molecular understanding of skeletal development. Cell. 1995; 80: 371-8.

46. MacLean HE, Kim JI, Glimcher MJ, Wang J, Kronenberg HM, Glimcher LH. Absence of transcription factor c-maf causes abnormal terminal differentiation of hypertrophic chondrocytes during endochondral bone development. Dev Biol. 2003; 262: 51-63.

47. Kronenberg HM. Developmental regulation of the growth plate. Nature. 2003; 423: 332-6

48. Bartosh TJ, Ylostalo JH, Mohammadipoor A, Bazhanov N, Coble K, Claypool $\mathrm{K}$, et al. Aggregation of human mesenchymal stromal cells (MSCs) into 3D spheroids enhances their antiinflammatory properties. Proc Natl Acad Sci U S A. $2010 ; 107$ : 13724-9.

49. Xie T, Li L. Stem cells and their niche: an inseparable relationship. Development. 2007; 134: 2001-6.

50. Fuchs E, Tumbar T, Guasch G. Socializing with the neighbors: stem cells and their niche. Cell. 2004; 116: 769-78

51. Dua HS, Shanmuganathan VA, Powell-Richards AO, Tighe PJ, Joseph A. Limbal epithelial crypts: a novel anatomical structure and a putative limbal stem cell niche. Br J Ophthalmol. 2005; 89: 529-32

52. Coroneo MT, Muller-Stolzenburg NW, Ho A. Peripheral light focusing by the anterior eye and the ophthalmohelioses. Ophthalmic Surg. 1991; 22: 705-11.

53. Higa K, Shimmura S, Miyashita H, Shimazaki J, Tsubota K. Melanocytes in the corneal limbus interact with K19-positive basal epithelial cells. Exp Eye Res. 2005; 81: 218-23.

54. Goldberg MF, Bron AJ. Limbal palisades of Vogt. Trans Am Ophthalmol Soc. 1982; 80: 155-71.

55. Vantrappen L, Geboes K, Missotten L, Maudgal PC, Desmet V. Lymphocytes and Langerhans cells in the normal human cornea. Invest Ophthalmol Vis Sci. $1985 ; 26: 220-5$.

56. Baum JL. Melanocyte and Langerhans cell population of the cornea and limbus in the albino animal. Am J Ophthalmol. 1970; 69: 669-76.

57. Dziasko MA, Armer HE, Levis HJ, Shortt AJ, Tuft S, Daniels JT. Localisation of epithelial cells capable of holoclone formation in vitro and direct interaction with stromal cells in the native human limbal crypt. PLoS One. 2014; 9: e94283.

58. Gipson IK. The epithelial basement membrane zone of the limbus. Eye (Lond). 1989; 3 ( Pt 2): 132-40.

59. Shanmuganathan VA, Foster T, Kulkarni BB, Hopkinson A, Gray T, Powe DG, et al. Morphological characteristics of the limbal epithelial crypt. Br J Ophthalmol. 2007; 91: 514-9.

60. Bernardo ME, Cometa AM, Pagliara D, Vinti L, Rossi F, Cristantielli R, et al. Ex vivo expansion of mesenchymal stromal cells. Best Pract Res Clin Haematol. 2011; 24: 73-81.

61. Buhring HJ, Battula VL, Treml S, Schewe B, Kanz L, Vogel W. Novel markers for the prospective isolation of human MSC. Ann N Y Acad Sci. 2007; 1106: 262-71.

62. Crisan M, Yap S, Casteilla L, Chen CW, Corselli M, Park TS, et al. A perivascular origin for mesenchymal stem cells in multiple human organs. Cell Stem Cell. 2008; 3: 301-13.

63. Chen CW, Montelatici E, Crisan M, Corselli M, Huard J, Lazzari L, et al. Perivascular multi-lineage progenitor cells in human organs: regenerative units, cytokine sources or both? Cytokine Growth Factor Rev. 2009; 20: 429-34.

64. Corselli M, Chen CW, Sun B, Yap S, Rubin JP, Peault B. The tunica adventitia of human arteries and veins as a source of mesenchymal stem cells. Stem Cells Dev. 2012; 21: 1299-308.

65. Katare R, Riu F, Mitchell K, Gubernator M, Campagnolo P, Cui Y, et al. Transplantation of human pericyte progenitor cells improves the repair of infarcted heart through activation of an angiogenic program involving micro-RNA-132. Circ Res. 2011; 109: 894-906. 
66. Campagnolo P, Cesselli D, Al Haj Zen A, Beltrami AP, Krankel N, Katare R, et al. Human adult vena saphena contains perivascular progenitor cells endowed with clonogenic and proangiogenic potential. Circulation. 2010; 121: 1735-45.

67. Traktuev DO, Merfeld-Clauss S, Li J, Kolonin M, Arap W, Pasqualini R, et al. A population of multipotent CD34-positive adipose stromal cells share pericyte and mesenchymal surface markers, reside in a periendothelial location, and stabilize endothelial networks. Circ Res. 2008; 102: 77-85.

68. Schwab KE, Gargett CE. Co-expression of two perivascular cell markers isolates mesenchymal stem-like cells from human endometrium. Hum Reprod. 2007; 22: 2903-11.

69. Dupas T, Rouaud T, Rouger K, Lieubeau B, Cario-Toumaniantz C, Fontaine-Perus J, et al. Fetal muscle contains different CD34+ cell subsets that distinctly differentiate into adipogenic, angiogenic and myogenic lineages. Stem Cell Res. 2011; 7: 230-43.

70. Dravida S, Pal R, Khanna A, Tipnis SP, Ravindran G, Khan F. The transdifferentiation potential of limbal fibroblast-like cells. Brain Res Dev Brain Res. 2005; 160: 239-51. 